forcible wrenching under anæsthesia and fixation in hyperextension offers the best mechanical advantage to wrist and fingers. In two instances $I$ have excised the prominent fragment with relief as regards pain but with no increase of mobility.

Liverpool, June 8th, 1909.

I am, Sir, yours faithfully, ROBERT JONES.

\section{MICROCOCCUS TETRAGENUS AS A PATHOGENIC ORGANISM.}

To the Editor of THE LANCET.

SIR, - In the Proceedings of the Royal Society of Medicine (Clinical Section) for April, 1909, Dr. H. von Ofenheim contributed a paper on the Vaccine Therapy of Septicæmia, in the course of which he commented on the scarcity of the literature concerning micrococcus tetragenus infections. I accordingly seems worth while to place on record my experience of that organism. In 1901-1902 I was serving in H.M.S. Galatea in home waters, and from the suppurations (boils, \&c.) which occurred recovered what organisms I could. In that ship I only once found a gelatinliquefying coccus (staphylococcus); I never found a streptococcus, but from all the cultures worked out I obtained what was, I have no doubt, micrococcus tetragenus. I recognised it in smears of sputa as well in that ship. I also found, once only, a pathogenic yeast growing in a venereal sore. I have never found M. tetragenus in other ships. M. tetragenus seemed to me to be associated with little pus formation, but to excite large phlegmons (extensive surrounding swelling and redness) and to cause much, sometimes profuse, serous discharge.

Dr. von Ofenheim speaks of a septicæmia in rats and mice caused by this organism. I do not think we had any mice in the ship, and rats must have been few, as I have no remembrance of them. In those days we did no blood cultures, and I am sorry to have no further information. Still, it is a matter of some interest that the same observer should have found micrococcus tetragenus frequently associated with the suppurations of one ship, yet never in those of another, both these ships being in English waters.

$$
\text { I am, Sir, yours faithfully, }
$$

$$
\text { W. H. HoME, }
$$

H.M.S. Daedalus, Bristol, May 30th, $1909 . \quad$ Fleet-Surgeon, R.N.

\section{THE AFTER-TREATMENT OF CATARACT EXTRACTION. \\ To the Editor of THE LANCET.}

SIR, - I have read Mr. A. Lawson's lecture in THE LANCET of May 29th on the after-treatment of cataract extraction with particular interest, because for the last 15 years I have adopted a different method which, I think, makes the patient more comfortable both in body and mind. So far no bad results have occurred which could reasonably be traced to the freedom my patients enjoy, and the number of extractions (about 700) is sufficient to have disclosed any serious dangers attaching to my plan.

After the operation the eye is covered with a small piece of cotton-wool, fitted carefully into the inner corner by the nose, and this is kept in place by a piece of fine isinglass plaster. The plaster is pulled just tight enough to exert a little pressure over the inner corner of the eye, but no pressure is made on the globe ; a very slight pressure in the corner will keep the lids closed. Over the wool, but not pressing on it, is placed a conical shield of Willesden roofing paper, and this is fixed in position with short strips of isinglass plaster, one over the bridge of the nose and the others on the cheek and forehead. The unoperated eye is never covered, nor are the hands tied; the shield will resist a hard blow, and the eye is never accidentally injured under it. A shield stuck on in this way is much more comfortable than any bandage round the head.

I do the operation in the morning and make the patient go to bed and keep very still all day, and the next morning, unless there is some special reason against it, which is very seldom the case, he gets up and sits in a chair, keeping fairly quiet. On the morning after the operation the shield is taken off, the wool changed, and a drop of atropine and cocaine applied; subsequently the eye is dressed each morning, but the atropine is not used oftener than is necessary to keep up the dilatation of the pupil. In the summer the patients are often out in the garden on the third or fourth day after the operation and derive much benefit from it they eat their ordinary food and, in fact, are not treated as sick people at all.

I never tell a patient to expect pain, but tell him that if he should chance to get any after the operation he need not be alarmed at it. A large number say they have no pain. I believe pain may be caused by pressure on the eye and by the heat of a thick dressing, and am therefore careful to use only a little wool and to apply what little pressure is necessary to keep the eye shut only in the corner. An empty anterior chamber is not necessarily a cause of pain, for it may be empty for days together without any pain at all. At one time I bandaged both eyes and kept the patients in bed, but gradually gave up such irksome details as seemed to be possibly unnecessary and, if so, harmful, and have thus arrived at my present plan.

There is nothing worse for old people than thoroughly to upset their accustomed way of life, and, by making " heavy weather" of their treatment, give them the idea that they are undergoing some dangerous process. Of course, anxiety is inseparable from surgery, but the surgeon should keep it to himself, and the more light-hearted the patient can be kept the better will he recover and the less will his pain hurt him. To blindfold a patient, handcuff him, feed him on slops, tell him to lie still in bed and keep his mouth open if he moves, and to expect pain-all this seems to me the best way to ensure that he shall be nervous and have pain; and if to this suggestive treatment is added a dose of chloral there is surely enough to account for the night terrors and dementia Mr. Lawson describes without the shock of the little operation. If all this treatment were necessary for the safety of the eye it would have to be endured, even though it is obviously bad for the patient. My experience convinces me that it is not necessary, and that patients may get through the operation for cataract without any material discomfort. I am, Sir, yours faithfully,

Southampton, June 1st, 1909. J. F. Butrar, M.B. Cantab.,

\section{THE EMMANUEL MOVEMENT AND THE MEDICAL PROFESSION.}

\section{Io the Editor of THE LANCET.}

SIR, - We are constantly in receipt of letters from your side of the Atlantic which show that there is a widespread misunderstanding among physicians, clergymen, and others as to the principles and methods of what has come to be known as the "Emmanuel Movement." Âs those who are responsible for the inauguration and general guidance of this work, we feel it to be our duty to correct this misconception, and to acquaint the British public with the real aims and motives of our undertaking. We ask you, therefore, to be good enough to publish the following statement :-

The fundamental purpose of the Emmanuel Movement is to ally in friendly coöperation the doctor of medicine, the psychologically qualified minister of religion, and the trained social worker with a view to the alleviation and arrest of those semi-nervous, semi-moral disorders which go by the name of "functional disorders of the nervous system." Hence, our aim is not to found or propagate a healing cult, or to practise medicine, or to substitute our activities for those of the physician. We could not do any of these things and at the same time retain our self-respect. On the contrary, our aim is to assist the physician in those eases where a moral. or spiritual problem is involved. From the very beginning we have associated ourselves with reputable medical men, and without the general coöperation of the medical profession our enterprise would come to an end. The whole work is under rigid medical control, as will be seen from the following rules which we have adopted: (1) No person shall be received for treatment unless with the approval of and having been thoroughly examined by his family physician, whose report of the examination shall be filed with the church clinic records; (2) no patient shall be referred for diagnosis or treatment to any specialist or assistant save with the advice and consent of the patient's own physician; (3) all patients who are not under the care of a physician must choose one, and be themselves in his care before they can receive treatment at Emmanuel Church. It thus rests 
wholly with the physicians and not with the clergymen to decide whether a patient should ke referred to a neurologist or other specialist, and which cases, if any, are suitable for treatment by moral and religious re-education. In view of these facts, we must decline to be held responsible for the action of any individual or organisation acting in contravention of any of these principles or methods. In England the committee which represents our work bears the title "Church and Medical Union."

We are, Sir, yours faithfully,

ELWOOD WORCESTER.

SAMUEL MCOоMB.

Emmanuel Church, Boston, U.S.A., May 24th, 1909

\section{CASE OF CEREBRAL HÆMORRHAGE FOLLOWED BY HYPERPYREXIA AND DEATH.}

To the Editor of THE LANCET.

Sir,-In The Lancet of May 15th, 1909, p. 1386, Mr. Vincent P. Norman describes a case under the above heading, and adds, "a clinical fact not often recorded if we judge from a perusal of literature bearing on the subject."

The above remark, and my having had a similar case some time ago, must be my excuses for recording the following. The case occurred on board the R.M.S. Oropesa, of the Pacific Steam Navigation Company. The patient, a lady, aged 53 years, was very stout and of plethoric appearance. Her husband informed me that she had always been in fairly good health, and as a rule took but little alcohol. Soon after leaving Lisbon, however, I noticed that she took a good quantity of red wine with her meals, and as we got into tropical heat the quantity was considerably increased. On the third day after leaving St. Vincent, Cape de Verde Islands, I noticed that her face was very congested, and I feared apoplexy. About 4 A.M. the following morning I was hurriedly sent for to see the lady in question, the steward informing me that she had had a "fit." On my arrival I found the patient quite unconscious, pupils were dilated and inactive, radial pulse could not be counted, respiration was at first markedly stertorous, becoming later Cheyne-Stokes in character, and there was complete relaxation of her extremities. Her face was very cyanosed and she was obviously dying.

The point, however, that impressed me most was the sensation of extreme heat imparted to my hand. I had felt nothing like it before, and for this reason I decided to take her temperature. In the axilla the thermometer registered $107.8^{\circ} \mathrm{F}$, and in the rectum $108.6^{\circ} \mathrm{F}$. To make sure that the thermometer was accurate I obtained another one, which gave precisely the same result. The patient died within an hour of my seeing her, and was buried at sea the next day. I am, Sir, yours faithfully,

Chelsea, S.W., June 4th, 1909 .

$$
\text { Morgan Richards, M.D., B.S. Durh. }
$$

\section{FERGUSSON $v$. MALVERN URBAN DISTRICT COUNCIL: APPEAL OF PLAINTIFF} BEFORE HOUSE OF LORDS.

\section{7o the Editor of THE LANCET.}

SIR,-Mr. F. W. Joshua writes under the above heading in your last issue " to prevent any misconception of the true state of facts that may arise from reading" my letter in your issue of May 29th. I cannot see that his letter is called for by anything I said in mine, nor can I see that it serves any useful purpose; but Mr. Joshua probably differs from me on this point. On the contrary, I think that his letter, far from fulfilling its object, renders the case liable to be misunderstood, as anybody reading it, and not having followed the case closely, would naturally conclude that my father had stolen the water-supply. Such a conclusion is quite wrong, and is detrimental to the character of a medical man; and it is on this account that I now beg the hospitality of your columns to enable me to correct the inevitable misapprehension that must arise from a perusal of Mr. Joshua's letter.

The jury found that Dr. Fergusson had no right to the water, because he could produce no documentary or other evidence that he was entitled to it. There is unimpeachable evidence that the pipe conveying the water had been exactly as it was found as long as Dr. Fergusson had occupied the establishment, 16 years, and that no alteration whatever had been made to it by anyone with his knowledge or on his behalf. It was probably the original means of supply from the time when the house was built in 1843 , a time when no public supply existed and when anybody was at liberty to take water wherever it was to be found. This explains the absence of evidence as to ownership, and the jury had no alternative to finding that my father had no legal right to it.

The idea that he was fraudulently using it is negatived by the fact that the jury found him not guilty of contributory negligence, as was alleged by the defendants. Some of the wild assumptions and ridiculous conjectures which the jury were asked to believe, nithout evidence, were of a damaging character, and included the idea of my father having stolen the water. Repetition of these assumptions in the House of Lords was promptly cut slort by the Lords asking pointblank whether there was any evidence whatever in support of them; as the Lord Chancellor said, "We want facts, not theories."

I think I have said enough to justify the last paragraph of my letter in your issue of May 29th, and to correct the impression which must be left by Mr. Joshua's letter; my father has through no fault of his own lost his case, but has emerged with a clean character, in spite of much "mud. throwing," and on that account he deserves the sympathy of all, especially his professional brethren.

I am, Sir, yours faithfully,

J. N. F. Fergussion, M.B. Cantab.

Malvern II ydropathic Establishment, Great Malrern, June 9th, 1909

\section{A PLEA FOR THE USE OF ANTI DIPHTHERITIC SERUM}

\section{To the Editor of THE LANCET.}

SiR,-In my letter published in THE LANCET of June 5th under the above heading the report of Case 1 should have read as follows :-

"I saw C. D. on Nov. 5th, 1906, at 9 A.M., with quinsy, soft palate very red and cdematous, with a patch of membrane on left tonsil. He had been using hot inhalations of Friar's balsam but could not swallow. At 10.30 A.M. I injected 4000 B. U. and at 10 P.M., when I again visited him, he could swallow easily; a swab was taken with negatipe results. The next day he had a prafuse scarlet fever rash. The case ran an ordinary course, but the quinsy aborted." In my communication the words which I have italicised were inadvertently omitted, ancl as they form the central feature of the case I trust you will allow me space to correct the slip.

I am, Sir, yours faithfully,

Wanstead, N.E., June 5th, 1909

Frank ARgLES

\section{THE GERMAN CONGRESS OF INTERNAL MEDICINE.}

(From our Bertin Correspondent.)

THE German Congress of Internal Medicine was held at Wiesbaden from April 19th to 22nd, Professor ScHULTZE (Bonn) being in the chair.

\section{Discases of the Stomach.}

Professor LeNHARTZ (Hamburg) presented a report on the results obtained by his method in the treatment of gastrio ulcer. I may here mention that copious details of the method were contributed by Dr. J. Victor Haberman of Hamburg to The LANCET of July 7th, 1906, p. 25. Professor Lenhartz said that the special features of his system included absolute rest in bed for at least four weeks and the wearing of an ice-bag over the stomach. Instead of the usual starvation diet the patient, even when hæmatemesis bas occurred, reccived on the first day iced milk and four beaten-up eggs, sometimes with a little wine. The daily quantity of food was gradually increased, so that on the seventh day the patient began to take eight eggs, 40 grammes of sugar, 800 grammes of milk, 70 grammes of chopped raw meat, and 100 grammes of milk and rice; 